\title{
Women's autonomy in health decision- making and its effect on access to family planning services in Senegal in 2017: a propensity score analysis
}

\author{
N. M. Sougou ${ }^{1,2,3^{*}}$, O. Bassoum¹, A. Faye ${ }^{1,2}$ and M. M. M. Leye ${ }^{1,2}$
}

\begin{abstract}
Background: The effect of women's autonomy in decision-making for fertility control has been highlighted by research. The objective of this study was to analyze the effect of women's autonomy over decision-making regarding their health and access to family planning in Senegal in 2017.

Methods: The analyses in this study were carried out using data from the Senegal Demographic and Health Survey in 2017. The sample consisted of 8865 women aged 15-49. The propensity score-matching method was applied. Autonomy in health decision-making was considered the treatment variable. Matching was performed using confounding variables. The outcome variables were the current use of modern contraceptive methods and the existence of unmet needs. The common support condition had been met. The analysis was conducted using STATA.15 software.

Results: This study showed that $6.26 \%$ of women had decision-making autonomy in relation to their health. For $80.33 \%$ of the women, their husbands/partners made health-related decisions for them. Decision-making autonomy increased significantly with the age of the woman $(p<0.05)$. In addition, $15.24 \%$ of women were using a modern method of contraception. An estimated $26.2 \%$ of women had unmet needs. Propensity score matching split the women into two groups based on autonomy over decision-making for their health. After matching, there was no longer a significant difference between women who were autonomous with respect to their decision-making and those who were not autonomous with respect to their current use of a modern contraceptive method. On the other hand, there was a $14.42 \%$ reduction $(p<0.05)$ in unmet needs for family planning in the group of women who were autonomous with respect to their health decision-making.

Conclusion: Autonomy in health decision-making would reduce unmet needs among Senegalese women. These results show the importance of accounting for gender in health interventions for the accessibility of family planning services.
\end{abstract}

Keywords: Autonomy of decision-making for health, Family planning, Senegal

\footnotetext{
* Correspondence: ndeyemareme.sougou@ucad.edu.sn

${ }^{1}$ Department of Preventive Medicine and Public Health, University of Cheikh

Anta Diop, Dakar, Senegal

${ }^{2}$ Institute of Health Development, University of Cheikh Anta Diop, Dakar,

Senegal

Full list of author information is available at the end of the article
}

(c) The Author(s). 2020 Open Access This article is licensed under a Creative Commons Attribution 4.0 International License, which permits use, sharing, adaptation, distribution and reproduction in any medium or format, as long as you give appropriate credit to the original author(s) and the source, provide a link to the Creative Commons licence, and indicate if changes were made. The images or other third party material in this article are included in the article's Creative Commons licence, unless indicated otherwise in a credit line to the material. If material is not included in the article's Creative Commons licence and your intended use is not permitted by statutory regulation or exceeds the permitted use, you will need to obtain permission directly from the copyright holder. To view a copy of this licence, visit http://creativecommons.org/licenses/by/4.0/. The Creative Commons Public Domain Dedication waiver (http://creativecommons.org/publicdomain/zero/1.0/) applies to the data made available in this article, unless otherwise stated in a credit line to the data. 


\section{Background}

In 2015, 303,000 women died during or after pregnancy or childbirth. Most of these deaths occurred in lowincome countries, and most of them could have been prevented [1]. Access to contraception has been described as one of the key interventions to combat maternal mortality. In 2017, $63 \%$ of women worldwide were using some form of contraception. Contraceptive use was above $70 \%$ in Europe, Latin America, the Caribbean, and Northern America, while it was low (at 25\%) in Central and Western Africa [2]. In Senegal, despite the implementation of numerous health interventions, the use of modern contraceptive methods among couples remained low, with a contraceptive prevalence rate of $18.9 \%$ and a high rate of unmet needs for family planning (25.2\%) [3]. In Senegal, progress in family planning has long been reflected in a gradual increase in women's current use of modern contraceptive methods, while the unmet need rate remains high [4]. The latter represent women who either wish to avoid all pregnancies or to space out or limit future pregnancies and yet do not use modern contraception [5]. According to some studies, the reasons for these unmet needs are related to access to family planning services on the one hand and to the behavioral characteristics of women and their partners on the other hand [6].

Some studies had already focused on identifying factors associated with the use of family planning services. The determinants identified were factors related to sociodemographic characteristics (place of residence, women's level of education, socioeconomic level), factors related to the health system (insufficient family planning services) and sociocultural factors [7]. However, few studies have focused on gender relations within family and social structures and their implications for contraceptive practices. Nevertheless, in some African countries, contraceptive knowledge and practices were influenced by sociocultural norms such as the domination of men and husbands, opposition to contraception, and the lower social status of women [8]. Women's participation in fertility decisionmaking has been described as a determinant of contraceptive practices [7]. Recent research and policy discourse generally view the limited autonomy of women in developing countries as a major obstacle to improving their reproductive health [9-11]. The objective of this study was to investigate the relationship between women's autonomy over health decision-making and family planning. This study will make it possible to show the involvement of gender relations in the reduction of unmet needs for contraception in Senegal.

\section{Methods}

\section{Type of study}

The study was cross-sectional, descriptive and analytical.

\section{Data}

This study consisted of a secondary analysis of data from the Senegal Demographic and Health Survey (DHS) 2017, a nationally representative survey of 8865 women aged 15-49. The sample from the 2017 Continuous DHS is representative at the national level, at the regional level, and for both urban and rural areas [12]. The sample was drawn stratum by stratum. Thus, the sample is based on a stratified, two-stage area survey. At the first stage, 400 clusters (primary survey units) were drawn from the list of enumeration areas established during the General Census of Population and Housing, Agriculture and Livestock conducted in 2013, using a systematic draw with probability proportional to size, the size of the primary survey units being the number of households. A count of households in each of these clusters provided a list of households from which a sample of 22 households per cluster were drawn at the second stage with equal probability systematic sampling in both urban and rural areas. A total of 8800 households (4092 urban and 4708 rural) were selected.

The survey included detailed information on fertility, nuptiality, sexual activity, fertility preferences, knowledge and use of family planning methods. Data were collected using four questionnaires: (i) the household questionnaire, (ii) the women's questionnaire, (iii) the men's questionnaire, and (iv) the biomarker questionnaire. These four collection tools are based on the DHS Program's model questionnaires and have been adapted with respect to Senegal's demographic and health context.

The individual record (IR) file was used for the analysis. This female individual questionnaire was used to record information from women aged 15-49 who were residents or visitors the night before the survey.

The explanatory variable was women's autonomy over decision-making for their health. This variable was generated from the DHS variable "person who usually decides on respondent's health care (women)". This variable had 5 modalities: the respondent herself, the respondent and her husband/partner, the husband/partner alone, someone else and others. The variable was recoded as a binary variable. This variable was binary and coded 1 (has autonomy over decision-making for her health) and 0 (does not have autonomy over decision-making for her health). The outcome variables were contraceptive use and the existence of unmet needs.

The outcome variable "contraceptive use" was a binary variable coded as "1" (currently uses a contraceptive method) and "0" (does not use a contraceptive method). The outcome variable "existence of unmet need" was binary with 2 modalities: "existence of an unmet need for contraception" (coded 1) and "no unmet need for contraception" (coded 0). 
The matching variables in this analysis were those that had been identified as potentially confounding the association between decision-making power and the existence of unmet needs in this subpopulation of women. The individual factors included the following: (1) age was analyzed by 4-year age groups (15-19 years; 20-24 years; 25-29 years; 30-34 years; 35-39 years; 40-44 years; and 45-49 years); (2) women's marital status was classified as "never in a union", "married", "in a union", "widowed", "separated" and "divorced"; and (3) women's educational level was classified as "uneducated", "primary", "secondary" and "tertiary". The household factors included the following: (1) household wealth - the wealth index, a measure of relative economic well-being based on household assets, was classified into quintiles (lowest, second, middle, fourth, highest) and was derived from the wealth score; and (2) place of residence was dichotomized into "urban" or "rural".

\section{Analysis}

Data were explored, and frequencies and cross-tabulations were generated to clarify the distribution patterns of the variables of interest. Tests of comparisons of means were performed on the variables of interest in relation to decision-making power.

Potential selection biases were corrected by establishing a propensity score for women's exposure to decisionmaking autonomy (see Table 1).

After testing the common support hypothesis, the propensity score was calculated for all women using a multivariate logistic regression that included the covariates elicited. The propensity scores thus obtained, i.e., the conditional probability of women being able to independently make decisions regarding their health, allowed for matching between two groups. Propensity score analysis is a method of adjustment that consists of deriving the conditional probability (the propensity score) of a patient to receive the treatment being evaluated, knowing her characteristics measured upon inclusion. Matching each treated subject to an untreated subject with an identical or close propensity score results in the formation of two groups of subjects with comparable characteristics and between whom the criterion of judgment can be compared [13].

We used the STATA PSMATCH2 module of STATA.15 software to perform 5:1 matching [14]. We used the neighbors function (5).

The outcome variables were "contraceptive use" and "unmet need". Simple logistic regression models were constructed to examine the unadjusted and adjusted effects of women's decision-making power on the current use of modern contraceptives and the existence of unmet needs among Senegalese women aged 15-49.

\section{Results}

\section{Participants}

In our study, a secondary analysis of the Senegal 2017 DHS data was performed. Participants from urban and rural areas were selected from all 14 administrative regions of Senegal. The study focused on health decisionmaking among women aged 15-49.

After the issue of missing responses was addressed, the population size for our study was 5147 women. The flow diagram of the study population is represented in Fig. 1.

\section{Characteristics of women}

Sociodemographic, economic and behavioral characteristics among women aged 15-49.

A total of $66.5 \%$ of women were uneducated (see Table 2).

Women's autonomy over decision-making.

The study showed that $6.26 \%$ of women had the latitude make their own decisions about their health, while for $80.33 \%$, their husbands or partners made such decisions for them (see Table 3).

Women's autonomy over decision-making increases with age (see Fig. 2).

Women living in rural areas have less autonomy over decision-making for their health (OR: 0.54[0.43-0.68]). Women with a higher level of education are 5.5 times more likely to have autonomy over decision-making. Richer and wealthier women have more autonomy over decision-making, with ORs of 2.74 [1.59-4.70] and 2.88

Table 1 Distribution of variables according to access to health or non-health decision making before and after matching

\begin{tabular}{|c|c|c|c|c|c|c|}
\hline & \multicolumn{6}{|c|}{ Autonomy in relation to the decision for their health } \\
\hline & \multicolumn{3}{|c|}{ Before pairing } & \multicolumn{3}{|c|}{ After pairing } \\
\hline & Yes & No & $\mathrm{p}$ & Yes & No & $\mathrm{p}$ \\
\hline & $\%$ & $\%$ & & $\%$ & $\%$ & \\
\hline Age (under 19 years) & 36.79 & 10.07 & 0.0003 & 36.79 & 36.79 & 1 \\
\hline Place of residence & 15.55 & 16.97 & 0 & 15.55 & 15.55 & 0.96 \\
\hline Women's level of education & 55.85 & 45.62 & 0.02 & 55.85 & 53.11 & 0.71 \\
\hline Level of poverty & 27.95 & 24.61 & 0 & 27.96 & 28.03 & 0.91 \\
\hline Marital status & 96.32 & 99.50 & 0 & 96.32 & 96.32 & 1 \\
\hline
\end{tabular}




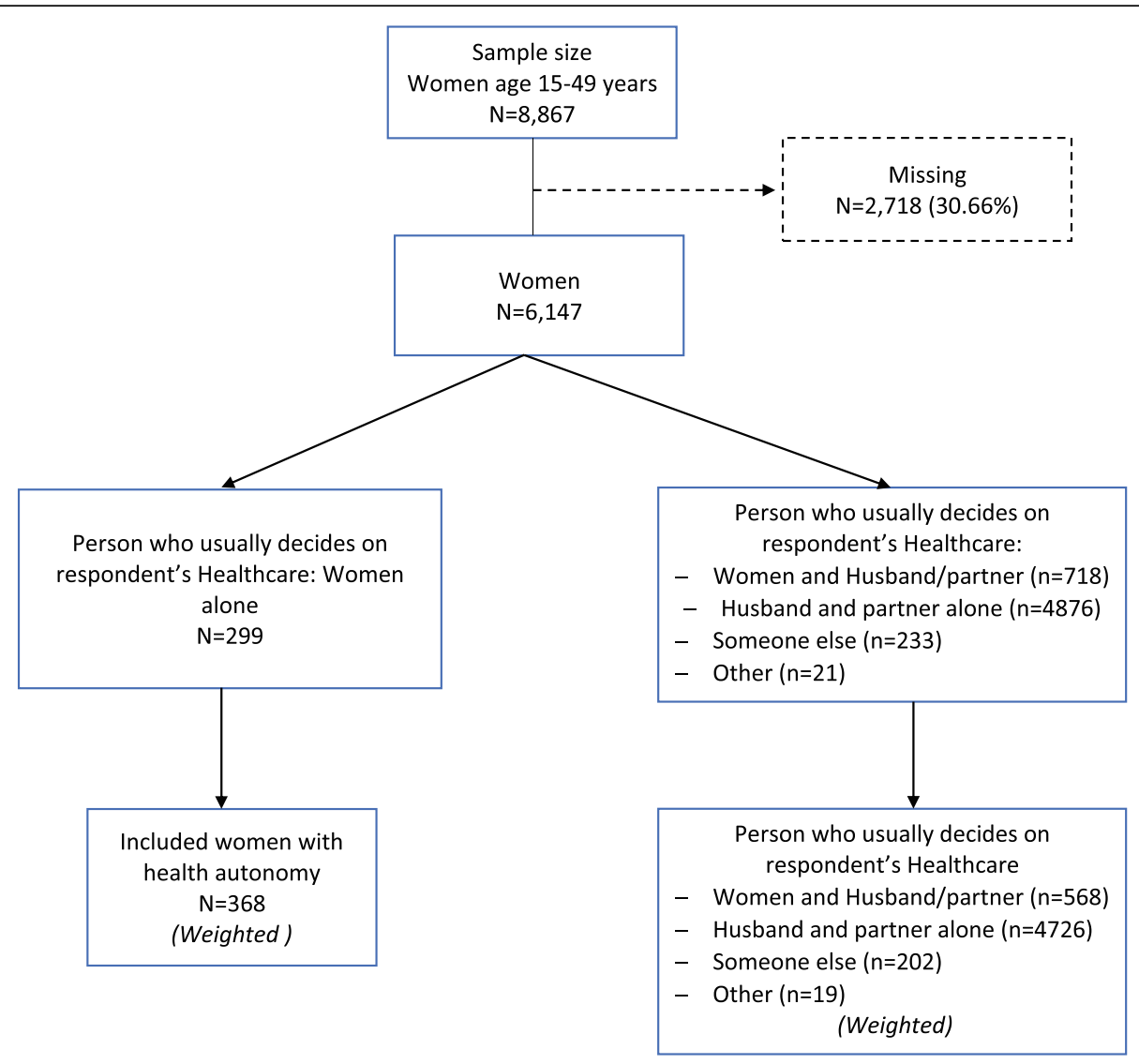

Fig. 1 Diagram flow of the population of study

[1.73-4.79], respectively. Women in unions (cohabitation) have more autonomy over decision-making. Women whose partners/husbands are educated have more autonomy over decision-making for their health (OR: 2.49 [1.37-4.52] and OR: 2.66 [1.35-5.24] for primary and secondary education of partners/husbands, respectively). Educated women also have more autonomy over decision-making (OR: 5.52 [3.06-9.94]) (see Table 4).

\section{Contraceptive use}

In this study, contraceptive prevalence was estimated at $17.9 \%$ of women in Senegal.

The most commonly used modern contraceptive methods are injectables (5.75\%), implants (5.21\%) and pills (3.11\%) (see Table 5).

In this study, the prevalence of women with unmet needs was $26.2 \%$.

Among women using contraception, 2.14\% have autonomy over decision-making for their health. Among women with unmet needs, only $0.09 \%$ have autonomy over decision-making for their health.

Propensity score adjustment.

Unmet needs were reduced by $14.42 \%$ in the group of women with autonomy over health decisions $(p<0.05)$.
There were no differences in contraceptive use between the 2 groups of women (Table 6).

\section{Discussion}

Factors associated with decision-making autonomy among Senegalese women

In Africa, the family environment is the locus of the relationship of domination between the sexes, the aim of which remains the subordination of gender [15]. Studies on gender and development have made it possible to highlight the contribution of "empowerment", or access to autonomy, which is at the heart of the resolution of social inequalities linked to gender [16].

In Senegal, women's autonomy over decisionmaking for their health is still weak. Our study has shown that only $6.26 \%$ of women have the latitude to make decisions regarding their own health. For most women $(80.33 \%)$, their husbands or partners decide for them. Elsewhere, in several developing countries, studies have shown how certain cultural norms affect women's autonomy in making decisions about their health [17]. It is mainly about the domination of the husband/partner, who often makes decisions for women on health issues [18]. 
Table 2 Distribution of socio-demographic, economic and behavioral characteristics among women aged 15-49 (weighted) [Senegal DHS, 2017]

\begin{tabular}{|c|c|c|c|}
\hline & Freq & $\begin{array}{l}\text { Percent } \\
\%\end{array}$ & Missing \\
\hline \multicolumn{4}{|l|}{ Age } \\
\hline $15-19$ & 1998 & 22.5 & \\
\hline $29-24$ & 1664 & 18.77 & \\
\hline $25-29$ & 1529 & 17.19 & \\
\hline $30-34$ & 1318 & 14.87 & \\
\hline $35-39$ & 998 & 11,26 & \\
\hline $40-44$ & 806 & 9.09 & \\
\hline $45-49$ & 557 & 6.28 & \\
\hline \multicolumn{4}{|l|}{ Place of residence } \\
\hline Rural & 4514 & 50.92 & \\
\hline Urban & 4351 & 49.08 & \\
\hline \multicolumn{4}{|l|}{ Level of education } \\
\hline Uneducated & 4310 & 48.62 & \\
\hline Primary level & 1967 & 22.19 & \\
\hline Secondary level & 2241 & 25.28 & \\
\hline Higher level & 347 & 3.91 & \\
\hline Level of education of husband/partner & & & $2339(26.38 \%)$ \\
\hline Uneducated & 4073 & 66.55 & \\
\hline Primary level & 607 & 9.62 & \\
\hline Secondary level & 584 & 9.25 & \\
\hline Higher level & 297 & 4.70 & \\
\hline Don't know & 750 & 11,88 & \\
\hline \multicolumn{4}{|l|}{ Wealth index } \\
\hline the poorest & 1475 & 16.64 & \\
\hline the poor & 1603 & 18.08 & \\
\hline the middle & 1749 & 19.73 & \\
\hline the rich & 1991 & 22.46 & \\
\hline the richest & 2046 & 23.08 & \\
\hline \multicolumn{4}{|l|}{ Marital status } \\
\hline Married & 3047 & 34.37 & \\
\hline Not Married & 5818 & 65.63 & \\
\hline
\end{tabular}

This study shows that women's power to make their own health-related decisions increases with their age. Other studies have shown the influence of age on women's empowerment [19]. In other countries in Africa, few women are empowered to make decisions about their own health [20]. Several studies in developing countries have also shown the positive influence of women's advanced age on their access to autonomy in decision-making about their health [21]. The older a woman becomes in traditional African societies, the more autonomous she becomes. The social construction of women's position and their position changes according to their age and their role in society [22]. However, in various traditional societies, women may appear to be important, influential or even autonomous, but compared to men of the same age, their positions generally suffer from a lack of recognition and value [23].

Our study showed that women in the richest and wealthiest quintiles have more autonomy over decisionmaking. In Ethiopia, a study on access to decision-making autonomy for health reached similar conclusions. Women with a high socioeconomic level had better access to decision-making autonomy over their health [24].

One of the factors associated with decision-making autonomy is educational attainment. Thus, both the educational level of the woman and that of her partner are factors associated with women's decision-making autonomy. In our study, the highest level of education is associated with decision-making autonomy in relation to health. In Nepal, women's higher education was positively associated with autonomy in healthcare decision-making $(p<0.01)$, but their higher education was not significant relative to other outcome measures [25]. In other countries, increasing women's autonomy has been shown to be positively correlated with women's education [26].

In our study, women with educated partners/husbands had greater autonomy over decision-making for their health. These are generally men with primary and secondary education. Studies have shown that welleducated men tend to have fewer sexist ideologies [18]. Educating men is all the more important, as support from the partner and the family environment has been shown to have a positive impact on strengthening women's decision-making autonomy [27].

Table 3 Distribution of the person who decides for women's health according to these characteristics $(N=5883)$

\begin{tabular}{lll}
\hline Person who usually decides for woman's health Workforce. & Frequency & Percentage \\
\hline Woman herself & 368 & 6.26 \\
Woman in consultation with husband/partner & 568 & 9.66 \\
Husband/partner alone & 4726 & 80.33 \\
Someone else & 202 & 3.43 \\
Other & 19 & 0.32 \\
\hline
\end{tabular}




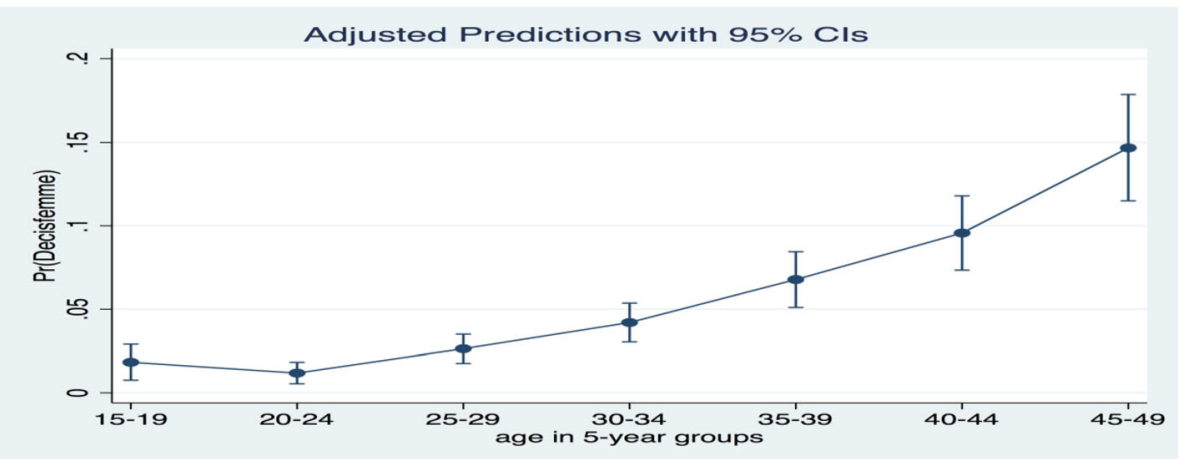

Fig. 2 Women's access to decision-making about their health according to their age

With low levels of education in the community, rural areas have shown limitations in supporting women. Studies have shown that family structure and gender relations in rural areas can influence women's autonomy [28] . In this study, women living in rural areas have less access to decision-making autonomy over their health. In Africa, patriarchy is often more developed in rural regions [29]. In addition, sociocultural burdens are more pronounced in rural areas [30].

In Senegal, despite numerous health interventions, the unmet need for contraception remains high. At the same time, the prevalence of contraceptives has increased in recent years [31]. This study showed an unmet need rate of $26.2 \%$ among Senegalese women. The persistence of

Table 4 Factors associated with women's decision-making autonomy

\begin{tabular}{|c|c|c|c|c|}
\hline Women's access to decision-making & $\begin{array}{l}\text { Percentage } \\
\%\end{array}$ & $p$ & OR & $\mathrm{Cl} 95 \%$ \\
\hline Place of residence & & 0 & & \\
\hline Rural & 2.23 & & 0.54 & $0.43-0.68$ \\
\hline Urban & 4.03 & & 1 & \\
\hline Level of education & & 0.003 & & \\
\hline Uneducated & 3.43 & & 1 & \\
\hline Primary level & 1.32 & & 1.08 & $0.66-1.8$ \\
\hline Secondary level & 0.85 & & 1.19 & $0.57-2.47$ \\
\hline Higher level & 0.66 & & 5.52 & $3.06-9.94$ \\
\hline Level of education of husband/partner & & 0.033 & & \\
\hline Uneducated & 64.55 & & 1 & \\
\hline Primary level & 9.62 & & 2.49 & $1.37-4.52$ \\
\hline Secondary level & 9.25 & & 2.66 & $1.35-5.24$ \\
\hline Higher level & 4.7 & & 1.92 & $0.88-4.16$ \\
\hline Don't know & 11.88 & & 0.97 & $0.55-1.72$ \\
\hline Wealth index & & 0.0007 & & \\
\hline the poorest & 0.71 & & 1 & \\
\hline the poor & 1.17 & & 1.77 & $1.07-2.94$ \\
\hline the middle & 0.85 & & 1.35 & $0,83-2.21$ \\
\hline the rich & 1.77 & & 2.74 & $1.59-4.70$ \\
\hline the richest & 1.75 & & 2.88 & $1.73-4.79$ \\
\hline Marital status & & 0.0001 & & \\
\hline Married & 5.91 & & 1 & \\
\hline In union & 1.1 & & 7.17 & $2.36-21.74$ \\
\hline
\end{tabular}


Table 5 Distribution of women according to the type of contraceptive method used

\begin{tabular}{lll}
\hline Current use of contraceptive method & $\begin{array}{l}\text { Percentage } \\
\%\end{array}$ & SE \\
\hline Does not use a method & 82.04 & 0.69 \\
Pills & 3.11 & 0.28 \\
IUD & 1.17 & 0.19 \\
Injectables & 5.75 & 0.31 \\
condom & 0.63 & 0.14 \\
female sterilization & 0.5 & 0.14 \\
Abstinence & 0.54 & 0.13 \\
Coil interrupted & 0.29 & 0.08 \\
Other methods & 0.56 & 0.1 \\
implants/norplant & 5.21 & 0.45 \\
LAM & 0.01 & 0.03 \\
collar & 0.04 & 0.02 \\
\hline
\end{tabular}

this unmet need for contraception suggests that health interventions have not yet addressed the determinants that keep the unmet need high. The study showed that autonomous decision-making for health reduces the rate of unmet needs by $14 \%(p<0.05)$. Thus, this study shows that women who continue to have unmet needs are women who are not autonomous in making decisions for their own health. For most (80.33\%), the primary decision-maker with respect to their health is their husbands.

Thus, this study highlights the importance of studying gender relations in understanding the factors limiting access to sexual and reproductive services. Elsewhere, in other developing countries, studies have shown how certain cultural norms affect women's autonomy in making decisions about their health $[17,18]$. These include, as in this study, the dominance of the husband/partner makes decisions for the woman in matters related to her health.

In addition, our study did not highlight a significant link between the use of a contraceptive method and decision-making power. On the other hand, the analysis of data from the DHS carried out in 32 countries in subSaharan Africa has shown a significant relationship between these two variables [32]. The methodological differences in terms of statistical analyses could explain these contradictory results.

\section{Limitations}

One of the major strengths of this study is the use of propensity scores, which eliminated the impact of selection bias inherent in observational studies (as opposed to randomized clinical trials, in which the principle is to achieve initial group comparability). This statistical method resulted in two groups that were comparable overall except for the explanatory variable (autonomy in decision-making). For statistical analysis, we used the STATA PSMATCH2 module of STATA.15 software to perform 5:1 matching. From a statistical point of view, some limitations can be pointed out regarding the use of the PSMATCH2 command rather than TEFFETCS. The STATA PSMATCH2 command has some advantages, as it allows the PSTEST command to be used to evaluate the comparability of the treatment and control groups according to the covariates specified before and after matching. However, the latter has some limitations that could have been considered by the TEFFECTS PSMATCH command. Indeed, with PSMATCH2, there is an insufficiency in the consideration of standard errors when calculating the propensity score.

Another strength of this study lies in the use of DHS data from Senegal, which are representative of Senegal. This makes it possible to generalize the results of the study to women of childbearing age in Senegal. However, this study has certain limitations. In particular, the analyses used cross-sectional data, so that only associations and no causal relationships were established. This study could be complemented by a qualitative study to clarify the social contexts in which gender relations evolve.

\section{Conclusion}

Based on the findings of this study, it is imperative to note that improving women's autonomy in decision-making for their health could contribute to the reduction of unmet needs. This study showed that women's empowerment for their health is associated with other immediate determinants, including their age, marital status, education, partner's education, living environment (rural/urban), wealth or socioeconomic status. Improving women's participation

Table 6 Effects of access to decision-making power on contraceptive use and unmet need among women after adjustment by propensity score

\begin{tabular}{|c|c|c|c|c|c|c|c|c|}
\hline & \multicolumn{8}{|c|}{ Autonomy in relation to the decision } \\
\hline & \multicolumn{4}{|c|}{ Before pairing } & \multicolumn{4}{|c|}{ After matching } \\
\hline & Yes & No & Difference & $\mathrm{p}$ & Yes & No & Difference & $\mathrm{p}$ \\
\hline & $\%$ & $\%$ & & & $\%$ & $\%$ & & \\
\hline Existence of unmet needs & 16.39 & 23.8 & 7.42 & 0.0032 & 16.44 & 30.87 & 14.43 & 0.001 \\
\hline Contraceptive use & 29.43 & 21.36 & -8.07 & 0.001 & 29.53 & 21.54 & -7.99 & 0.06 \\
\hline
\end{tabular}


in the labor force, which entails creating employment opportunities, reducing gender-based violence, strengthening their decision-making power and increasing their level of knowledge, could contribute to better access to family planning services and, above all, to reducing unmet needs, thus improving maternal health in Senegal. In addition, the development of transformative health programs would provide better access to sexual and reproductive health services for women. One of the recommendations of this study would be to promote the establishment of multisectoral collaboration in an integrated family planning program in Senegal. This multisectorality could include the education sector with interventions in favor of education and literacy for women and the microfinance and entrepreneurship sector in the context of the promotion of income-generating activities. In addition, the results of this study suggest that men should be enlisted in family planning awareness programs.

\section{Abbreviations}

OR: Odds ratio; Cl: Confidence intervals; DHS: Demographic Health Survey; SE: Standard error; National Ethics Committee (CNERS); LAM: Lactational amenorrhea method; IR: Individual record

\section{Acknowledgements}

Not Applicable.

\section{Authors' contributions}

NMS analyzed and interpreted the data. OB proceeded to verify the statistical tests. AF and MMML were major contributors in writing the manuscript. All authors read and approved the final manuscript.

\section{Funding}

Not applicable.

\section{Availability of data and materials}

The datasets analyzed during the current study are publicly available upon request at https://dhsprogram.com/data/available-datasets.cfm.

\section{Ethics approval and consent to participate}

This study was a secondary analysis of DHS data conducted in Senegal in 2017. The 2017 Senegal Demographic Health Survey (DHS) was approved by the National Ethics Committee (CNERS). The survey also obtained the visa of the Committee of Ethics (Institutional Review Board) of the ICF. The informed consent obtained from all participants was written.

\section{Consent for publication}

Not applicable.

\section{Competing interests}

The authors declare that they have no competing interests.

\section{Author details}

'Department of Preventive Medicine and Public Health, University of Cheikh Anta Diop, Dakar, Senegal. ${ }^{2}$ Institute of Health Development, University of Cheikh Anta Diop, Dakar, Senegal. ' ${ }^{3}$ MI 3189 « Environnement, Santé, Sociétés », UCAD, CNRS, CNRST, USTTB, UGB, Dakar, Senegal.

Received: 19 February 2020 Accepted: 27 May 2020

Published online: 05 June 2020

\section{References}

1. Alkema L, Chou D, Hogan D, Zhang S, Moller A-B, Gemmill A, et al. Global, regional, and national levels and trends in maternal mortality between 1990 and 2015, with scenario-based projections to 2030: a systematic analysis by the UN maternal mortality estimation inter-agency group. Lancet. 2016; 387(10017):462-74.

2. WFP2017_Highlights.pdf [Internet]. [cité 15 mai 2020]. Disponible sur: https://www.un.org/en/development/desa/population/publications/pdf/ family/WFP2017_Highlights.pdf.

3. Plan-dAction-Senegal.pdf [Internet]. [cité 5 sept 2019]. Disponible sur: https:/partenariatouaga.org/en/wp-content/uploads/2017/04/Plan-dActionSenegal.pdf.

4. Machiyama K, Cleland J. Analyse des besoins non satisfaits au Sénégal . Population Council; 2013 [cité 9 sept 2019]. Disponible sur: https:// knowledgecommons.popcouncil.org/departments_sbsr-rh/276.

5. Brochure_ReproductiveHealth-FR-v6.pdf [Internet]. [cité 9 sept 2019]. Disponible sur: https://www.countdown2030europe.org/storage/app/media/ Brochure_ReproductiveHealth-FR-v6.pdf.

6. Belohlav K, Nolan L. Besoins non Satisfaits en Planification Familiale et Demandes pour des Familles plus petites au Rwanda :4. Washington: Population Reference Bureau; 2013.

7. Melka AS, Beyene TT, Tesso DW. Determinants of long acting and permanent contraceptive methods utilization among married women of reproductive age groups in western Ethiopia: a cross-sectional study. Pan Afr Med J. 2015;21. [cité 5 sept 2019]. Disponible sur: http://www. panafrican-med-journal.com/content/article/21/246/full/.

8. Beekle AT, McCabe C. Awareness and determinants of family planning practice in Jimma, Ethiopia. Int Nurs Rev. 2006;53(4):269-76.

9. Oxaal Z, Baden S. University of Sussex, Institute of Development Studies, Sweden, Styrelsen för internationell utveckling. Gender and empowerment: definitions, approaches and implications for policy : briefing prepared for the Swedish international development office (Sida). Brighton: BRIDGE, Institute of Development Studies; 1997.

10. WHO_IER_MHI_STM.09.1_fre.pdf [Internet]. [cité 5 sept 2019]. Disponible sur: https://apps.who.int/iris/bitstream/handle/10665/70120/WHO_IER_MH_STM. 09.1_fre.pdf;jsessionid=78F6BDFD01C5DE54B91964027F10C352? sequence=1.

11. Mumtaz Z, Salway S. Understanding gendered influences on women's reproductive health in Pakistan: moving beyond the autonomy paradigm. Soc Sci Med. 2009;68(7):1349-56.

12. Rapport Final EDS 2017.pdf [Internet]. [cité 9 sept 2019]. Disponible sur: http:// www.ansd.sn/ressources/rapports/Rapport\%20Final\%20EDS\%202017.pdf.

13. Austin PC, Grootendorst P, Anderson GM. A comparison of the ability of different propensity score models to balance measured variables between treated and untreated subjects: a Monte Carlo study. Stat Med. 2007;26(4):734-53.

14. Leuven E, Sianesi B. PSMATCH2: Stata module to perform full Mahalanobis and propensity score matching, common support graphing, and covariate imbalance testing. 2018 [cité 13 sept 2019]. (Statistical Software Components). Disponible sur: https://econpapers.repec.org/software/ bocbocode/S432001.htm.

15. Imam AM, Mama A, Sow F. Sexe, genre et société engendrer les sciences sociales africaines. Paris: Karthala; 2004.

16. Touré M. La recherche sur le genre en Afrique : quelques aspects épistémologiques, théoriques et culturels. Genre et dynamiques socioéconomiques et politiques en Afrique: CODESRIA; 2011.

17. Singh SK, Sharma B, Vishwakarma D, Yadav G, Srivastava S, Maharana B. Women's empowerment and use of contraception in India: macro and micro perspectives emerging from NFHS-4 (2015-16). Sex Reprod Healthc Off J Swed Assoc Midwives. 2019;19:15-23.

18. Sultana AM. Factors effect on women autonomy and decision-making power within the household in rural communities. J Appl Sci Res. 2011;7(1):18-22.

19. Sado L, Spaho A, Hotchkiss DR. The influence of women's empowerment on maternal health care utilization: evidence from Albania. Soc Sci Med. 2014;114:169-77. https://doi.org/10.1016/ j.socscimed. 2014.05.047.

20. Alemayehu M, Meskele M. Health care decision making autonomy of women from rural districts of Southern Ethiopia: a community based crosssectional study. Int J Women's Health. 2017 [cité 9 avr 2020]. Disponible sur: https://www.dovepress.com/health-care-decision-making-autonomy-ofwomen-from-rural-districts-of\%2D\%2Dpeer-reviewed-fulltext-article-IJWH.

21. Osamor PE, Grady C. Women's autonomy in health care decision-making in developing countries: a synthesis of the literature. Int J Womens Health. 2016;8:191-202.

22. Amadiume PI. Male daughters, Female Husbands: Gender and Sex in an African Society. Londres et New Jersey: Zed Books Ltd; 2015. p. 248.

23. Rosaldo MZ, Lamphere L, Bamberger J. Woman, Culture, and Society. Stanford: Stanford University Press; 1974. p. 376. 
24. Nigatu D, Gebremariam A, Abera M, Setegn T, Deribe K. Factors associated with women's autonomy regarding maternal and child health care utilization in Bale Zone: a community based cross-sectional study. BMC Womens Health. 2014:14(1):79.

25. Acharya DR, Bell JS, Simkhada P, van Teijlingen ER, Regmi PR. Women's autonomy in household decision-making: a demographic study in Nepal. Reprod Health. 2010;7(1):15.

26. Ahmed S, Creanga AA, Gillespie DG, Tsui AO. Economic Status, Education and Empowerment: Implications for Maternal Health Service Utilization in Developing Countries. PLOS ONE. 2010;5(6):e11190

27. Speizer IS, Story WT, Singh K. Factors associated with institutional delivery in Ghana: the role of decision-making autonomy and community norms. BMC Pregnancy Childbirth. 2014;14(1):398.

28. Wathen CN, Harris RM. "I Try to Take Care of It Myself." How Rural Women Search for Health Information. Qual Health Res. 2007:17(5):639-51.

29. Conzo P, Fuochi $G$, Mencarini L. Fertility and life satisfaction in rural Ethiopia. Demography. 2017;54(4):1331-51. https://doi.org/10.1007/s13524-017-0590-2

30. Sanoudi S. Les pesanteurs socioculturelles, obstacles à l'engagement politique des femmes au Burkina Faso. Alizés: Revue angliciste de La Réunion, Faculté des Lettres et Sciences humaines (Université de La Réunion), 2011, Actes du colloque international "Genre et gouvernance" (île Maurice, 17-19 novembre 2009), pp.180-191. hal-02341446.

31. Cavallaro FL, Benova L, Macleod D, Faye A, Lynch CA. Examining trends in family planning among harder-to-reach women in Senegal 1992-2014. Sc Rep. 2017;7(1):41006.

32. Yaya S, Uthman OA, Ekholuenetale M, Bishwajit G. Women empowerment as an enabling factor of contraceptive use in sub-Saharan Africa: a multilevel analysis of cross-sectional surveys of 32 countries. Reprod Health. 2018;15(1):214

\section{Publisher's Note}

Springer Nature remains neutral with regard to jurisdictional claims in published maps and institutional affiliations.

Ready to submit your research? Choose BMC and benefit from:

- fast, convenient online submission

- thorough peer review by experienced researchers in your field

- rapid publication on acceptance

- support for research data, including large and complex data types

- gold Open Access which fosters wider collaboration and increased citations

- maximum visibility for your research: over $100 \mathrm{M}$ website views per year

At $\mathrm{BMC}$, research is always in progress.

Learn more biomedcentral.com/submissions 